\title{
FOREIGN AFFAIRS FEDERALISM AND THE SEPARATION OF POWERS
}

\author{
JoHn C. Yoo*
}

\begin{abstract}
$C$ rosby v. National Foreign Trade Council ${ }^{1}$ was the great test of federalism 1 that never was. To date, some have thought that the Supreme Court's ongoing reinvigoration of federalism has entailed no truly sweeping changes in doctrine and no stunning obstacles to the enforcement of federal policy. ${ }^{2}$ For example, in its recent cases striking down federal laws as beyond Congress' Commerce Clause power, the Rehnquist Court claimed to be staying true to precedent, as it has yet to overrule a single Commerce Clause case. ${ }^{3}$ The anti-commandeering cases, which prohibit the national government from forcing state executives and legislatures to carry out federal policies, also entailed no overruling of precedent and no great innovation in doctrine. ${ }^{4}$ Even the recent sovereign immunity cases required the Court to overrule only one shaky opinion. ${ }^{5}$ The New Federalism has yet to ask the Court either to move the doctrine in revolutionary directions or, I would argue, to fundamentally re-orient the balance of power between the federal government and the states.
\end{abstract}

* Professor of Law, University of California at Berkeley School of Law (Boalt Hall) (on leave); Deputy Assistant Attorney General, Office of Legal Counsel. This Article represents my personal views, and does not necessarily reflect the official position of the Department of Justice.

1. 530 U.S. 363 (2000).

2. See, e.g.. Jesse H. Choper \& John C. Yoo, The Scope of the Commerce Clause after Morrison, 25 OkLA. CrTy U. L. Rev. 843, 854 (2000) (emphasizing "limited impact of Lopez and Morrison themselves on the enforcement of federal policy"); Charles Fried, Revolutions?, 109 Harv. L. Rev. 13, 73 (1995) (noting that Supreme Court Justices "have been assiduous both to maintain and to demonstrate continuity with the past...").

3. See United States v. Morrison, 529 U.S. 598, 668-82 (2000) (holding that congressional statute regulating gender-motivated crimes is unconstitutional because regulating such crimes is outside scope of Congress' commerce power); United States v. Lopez, 514 U.S. 549, 552-68 (1995) (holding that Congress did not have power under Commerce Clause to pass Gun-Free School Zones Act because regulation had nothing to do with commerce).

4. See, e.g., Printz v. United States, 521 U.S. 898, 935 (1997) (holding that Congress cannot enact statute that compels state officials to carry out or administer federal regulatory scheme); New York v. United States, 505 U.S. 144, 188 (1992) (holding that "[t]he Federal Government may not compel the states to enact or administer a federal regulatory program").

5. See Pennsylvania v. Union Gas Co., 491 U.S. 1, 23 (1989) (holding that Congress has authority under Commerce Clause to make states liable for money damages in federal courts pursuant to Comprehensive Environmental Response, Compensation and Liability Act), overruled by Seminole Tribe of Fla. v. Florida, 517 U.S. 44 (1996). 
Crosby potentially presented the Court with just that opportunity. The First Circuit below had rested its decision striking down Massachusetts' Burma sanctions law on a particularly expansive form of federal power: dormant foreign affairs preemption. ${ }^{6}$ First appearing in Zschernig $v$. Miller, ${ }^{7}$ this doctrine requires federal courts to invalidate state laws-in the absence of any federal preempting statutes or actions-that interfere with the national government's power over international relations. ${ }^{8}$ Zschernig is not just a prudential or procedural rule; it symbolizes a deeper structural understanding of the balance of power between the federal and state governments. Zschernig rests on the idea that the nation preceded the states and that, therefore, the federal government is vested with all of the powers of national sovereignty-a notion that can trace itself not just to Justice Sutherland's opinion for the Court in United States $v$. Curtiss-Wright Export Corp.,${ }^{9}$ but also to the thoughts of Alexander Hamilton and the High Federalists of the framing period. ${ }^{10}$ Zschernig thus reverses the presumption of the Tenth Amendment and the implications of a Constitution of limited federal powers. Instead, this decision reserves to the federal government all powers in foreign affairs not specifically granted to the states. ${ }^{11}$ Just as the dormant Commerce Clause, from which it draws obvious strength, has come under criticism by some of the Justices, ${ }^{12}$ so too has the dormant foreign affairs doctrine recently received sharp academic questioning by those who argue that it makes no sense in light of the Court's recent federalism decisions. ${ }^{13}$

In Crosby, however, the Court avoided the question of whether the national government's dominance in foreign affairs would survive in this new age of federalism. Instead of revisiting Zschernig, writing for the Court, Justice Souter found that the Massachusetts law conflicted with a

6. See Nat'l Foreign Trade Council v. Natsios, 181 F.3d 38, 66-78 (1st Cir. 1999) (holding that Massachusetts Burma law violates Foreign Commerce Clause because it excessively interferes in foreign affairs).

7. 389 U.S. 429 (1968).

8. See Zschernig, 389 U.S. at 432 (holding Oregon statue unconstitutional because it was "an intrusion by the state into the field of foreign affairs which the Constitution entrusts to the President and the Congress").

9. 299 U.S. 304 (1936).

10. See generally The Feneralist (Jacob E. Cooke, ed. 1961) (defending proposed constitution and explaining its provisions).

11. See Zschernig, 389 U.S. at 441 (stating that " $[t]$ he Oregon law does . . . illustrate the dangers which are involved if each State . . . is permitted to establish its own foreign policy").

12. See Camps Newfound/Owatonna, Inc. v. Town of Harrison, 520 U.S. 564, 609-20 (1997) (Thomas, J., dissenting) (criticizing majority's use of dormant Commerce Clause).

13. See, e.g., Jack L. Goldsmith, Federal Courts, Foreign Affairs, and Federalism, 83 VA. L. Rev. 1617, 1617-18 (noting that foreign affairs law is seemingly "immune" to recent federalism "revolution"); Michael D. Ramsey, The Potuer of States in Foreign Affairs: The Original Understanding of Foreign Policy Federalism, 75 Notre Dame L. Rev. 341, 392-93 (1999) (discussing lack of foundation in Article I, Section 8 for dormant foreign affairs doctrine). 
federal sanctions law targeted at Burma because the state law stood as an obstacle to the accomplishment of federal policy goals. ${ }^{14}$ Justice Souter found that Massachusetts' effort to sanction companies doing business with Burma interfered with Congress' delegation of authority to the President to control the nation's economic actions against that nation. ${ }^{15}$ The Court further held that Massachusetts' law disrupted the ability of the political branches to calibrate the exact amount of American force to be used against Burma. ${ }^{16}$ Finally, the Justices concluded that here, state foreign policies conflicted with the statute's authorization to the President to seek a comprehensive multilateral solution on the Burma question in cooperation with our trading partners and allies. ${ }^{17}$ Rather than rely upon the apparently shaky dormant foreign affairs doctrine, the Court steered to the safer ground provided by standard conflict preemption doctrine. Under this doctrine, the Constitution's Supremacy Clause requires federal courts to suppress state laws that prevent federal laws from achieving their goals. ${ }^{18}$

While initially it appears that the Court avoided the deeper federalism questions potentially raised by Crosby, a second glance might suggest that the decision actually reinforces the notions behind Zschernig. This in part results from the Court's misinterpretations of the Burma law and its misunderstanding of the general allocation of the foreign affairs power among the branches of the federal government. The Court found the Burma law delegated the President power to impose economic sanctions upon Burma. ${ }^{19}$ But the Court failed to realize that the President already enjoyed that power under the International Emergency Economic Powers Act (IEEPA), and under that authority in the past the President enjoyed the ability to preempt state laws that interfered with his efforts to engage in international economic warfare. ${ }^{20}$ The Court also found that the statute authorized the President to conduct diplomatic negotiations to

14. See Crosby v. Nat'l Foreign Trade Council, 530 U.S. 363, 373 (2000) ("[W]e see the state Burma law as an obstacle to the accomplishment of Congress's full objectives under the federal Act.").

15. See id. at 373-74 (stating that state statute undermines federal Act's intention to delegate "effective discretion to the President to control economic sanctions against Burma ...").

16. See id. at 380-81 (noting that state statute prevented Legislative and Executive branches from setting policy regarding Burma).

17. See id. at 382-86 (noting that state statute interferes with Executive's ability to deal with allies and other foreign sovereigns).

18. See, e.g., Hines v. Davidowitz, 312 U.S. 52, 62-63 (1941) (holding that Supremacy Clause of Constitution prevents states from adding or taking away from treaties or statutes constitutionally established by national government).

19. See Crosby, 530 U.S. at 369 (stating that "the federal Act authorizes the President to impose further [economic] sanctions").

20. See Dames \& Moore v. Regan, 453 U.S. 654, 670-74 (1981) (holding that Executive has power to preempt state law under International Emergency Economic Powers Act). 
achieve a multilateral solution to the Burma problem. ${ }^{21}$ But of course, as any student of American foreign relations law knows, the President already enjoys plenary authority to conduct diplomacy with other nations as he sees fit. If one reads the federal Burma sanctions law as not really altering the status quo of federal international economic law, then the Court would have reached the same result in Crosby regardless of the presence of a federal statute.

Nonetheless, I think that if the current Court were presented with a true dormant foreign affairs case, the deeper theory evident in Crosby might lead to a contrary result. Crosby, it seems to me, is more of a separation of powers case than a federalism case. Much of the Court's language does not emphasize the federal government's powers in foreign relations-instead, it praises the President's powers. It is the President, according to the Court, who must enjoy the freedom and discretion to carefully calibrate national economic sanctions so as to produce the desired amount of carrot and stick in our international relations. Indeed, in other cases, such as United States $v$. Belmont ${ }^{22}$ and Pink $v$. United States, ${ }^{23}$ the Court has preempted state laws that interfered with the President's unilateral conduct over economic foreign relations, vis-à-vis the Soviet Union. ${ }^{24}$ It is the President whose diplomatic powers would be hampered by Massachusetts' Burma sanctions law. Massachusetts violated the Constitution because it infringed on the President's ability to conduct our foreign relations. "Within the sphere defined by Congress, then, the statute has placed the President in a position with as much discretion to exercise economic leverage against Burma, with an eye toward national security, as our law will admit," the Court declared. ${ }^{25}$ The Court further stated that "it is just this plenitude of Executive authority that we think controls the issue of preemption here." 26 And, it added, "Again, the state Act undermines the President's capacity, in this instance for effective diplomacy." ${ }^{27}$ The Massachusetts law "compromise[s] the very capacity of the President to speak for the Nation with one voice in dealing with other governments." ${ }^{28}$

The same reasons why the Court favors the President, however, would lead it to reject a vigorous dormant foreign affairs doctrine. First, let me sketch out why courts and many scholars have long favored presidential control of foreign affairs. The obvious reason is that the Executive branch

21. See Crosby, 530 U.S. at 369 (noting that federal statute authorizes President to develop comprehensive and multilateral strategy to bring democracy to Burma).

22. 301 U.S. 324 (1937).

23. 315 U.S. 203 (1942).

24. See Pink, 315 U.S. at 231-33 (striking down state action that interfered with President's power to establish foreign policy with Soviet Union); Belmont, 301 U.S. at 325-32 (same).

25. Crosby, 530 U.S. at 375-76.

26. Id. at 376 .

27. Id. at 381 .

28. Id. 
enjoys clear structural superiorities in the conduct of international relations.

It is helpful here to examine the theories developed by political scientists and economists that attempt to model international relations. Put simply, these scholars begin with the assumption that the international system is governed by anarchy in which nations seek to maximize their security and power. ${ }^{29}$ Realists believe that this situation leads nations to secure their survival through the unilateral buildup of their armed forces. ${ }^{30}$ Others, sometimes known as institutionalists, believe that even in a state of anarchy, nations may engage in forms of cooperation that allow them to overcome prisoners' dilemmas in areas such as trade and the environment. ${ }^{31}$

Despite their differences, both realists and institutionalists assume that nation-states employ a rational actor approach to national security decision-making. The primary requirement for the study of national strategy, according to Thomas Schelling's classic work, The Strategy of Conflict, is "the assumption of rational behavior-not just of intelligent behavior, but of behavior ... motivated by a conscious calculation of advantages, a calculation that in turn is based on an explicit and internally consistent value system." 32 The nation-state ideally is a rational, unitary decision-maker that can identify threats, develop responses and evaluate the costs and benefits which arise from different policy options. ${ }^{33}$ The rational actor translates broad national security interests into more discrete goals, which it then seeks to achieve by adopting value-maximizing policies and actions. ${ }^{34}$

International relations scholars have identified several institutional structures that lead to the effective exercise of power to achieve foreign policy goals. Nation-states require organizations that recognize the values and objectives that are to be maximized, that can identify and compare the costs and benefits of different policy options, that can collect and evaluate information, that can communicate policy decisions to arms of the state, that can communicate with other nations, and that can evaluate results and receive feedback. ${ }^{35}$ As Schelling writes, a nation-state would want "to have a communications system in good order, to have complete information, or to be in full command of one's own actions or of one's own assets." 36 While this model, no doubt, is difficult to achieve in the

29. See generally Kenneth N. Waltz, A Theory of International Politics (1979) (defining realism).

30. See id. at 183-92 (describing use of force under realist school of thought).

31. See, e.g., Robert O. Keohane, After Hegemony: Cooperation and DisCORd IN THE WORLD POLITICAl ECONOMY 7-9 (1984) (defining institutionalism).

32. Thomas C. Schelling, The Strategy of Conflict 4 (1960).

33. See Graham T. Allison, Essence of Decision: Explaining the Cuban MissiLE CRISIS 32-33 (1971) (describing nation-state rational actor paradigm).

34. See id. (explaining ideal national decision-making model for nation-state).

35. See generally id. (describing ideal decision-making national security models for nation-state).

36. SChelling, supra note 32 , at 18. 
real world-bureaucratic or political imperatives may distort policy, certain issues may allow domestic interests to overcome the national interest as identified by the rational actor-it remains an ideal that some theorists believe ought to guide effective foreign policy. ${ }^{37}$ It seems obvious that, in the modern world, only the Presidency meets the requirements of the rational national actor.

One can see the influences of this ideal even before its formal expression in recent political science. In Curtiss-Wright, for example, the Court famously (or notoriously) observed: "In this vast external realm, with its important, complicated, delicate and manifold problems, the President alone has the power to speak or listen as a representative of the nation." 38 Quoting from a Senate report, Justice Sutherland further explained that "[ $t]$ he nature of transactions with foreign nations ... requires caution and unity of design, and their success frequently depends on secrecy and dispatch." ${ }^{39}$ Such ideas can trace their origins in American political thought as far back as Alexander Hamilton, who wrote in The Federalist No. 70 that "[d]ecision, activity, secrecy, and dispatch will generally characterise the proceedings of one man, in a much more eminent degree, than the proceedings of any greater number; and in proportion as the number is increased, these qualities will be diminished." 40 As a result, the Framers vested the President with the Commander-in-Chief power, the power to make treatises with the advice and consent of the Senate, and the power to conduct diplomatic relations. ${ }^{41}$ Therefore, the history of American foreign relations and the American presidency has been the story of the expansion of the Executive's power thanks to its structural abilities to wield power quickly, effectively and in a unitary manner. ${ }^{42}$

If we accept this ideal of foreign relations decision-making, then it seems clear that a vigorous dormant foreign relations doctrine, of the sort suggested by Zschernig and avoided in Crosby, falls short. If there is any institution in our national government that would fail the unitary, rational actor test, it is the federal judiciary. The federal courts operate as a slow, decentralized, and at times, irrational bureaucracy. Take the makeup of the federal courts as an example. There are ninety-four district courts,

37. See id. at 16-20 (explaining that rational behavior model is ideal model for foreign affairs).

38. United States v. Curtiss-Wright Exp. Corp., 299 U.S. 304, 319 (1936).

39. Id.

40. The Federalist No. 70, at 472 (Alexander Hamilton) (Jacob E. Cooke ed., 1961).

41. See U.S. Const. art. II, $\$ 2$ (granting President specific foreign affairs powers).

42. See, e.g., Harold H. Koh, The National Security Constitution: Sharing Power After the Iran-Contra Affair 118-23 (1990) (explaining that structure of American government allows President to take initiative in foreign affairs); Arthur M. Schlesinger, Jr., The Imperial Presidency 35-67 (1973) (describing rise of unilateral presidential action in sphere of foreign affairs). 
composed of at least 647 independent judges. ${ }^{43}$ Each of these courts can hold ninety-four different opinions concerning the question of whether a state law interferes with national foreign policy objectives. There are thirteen federal courts of appeals, with 179 judges. ${ }^{44}$ Due to the Court's sparing use of its certiorari jurisdiction, these judges represent the court of last resort for more than $99 \%$ of all cases brought in federal court. ${ }^{45}$ Until the Supreme Court chooses to intervene, each of these circuit courts of appeals can enforce different opinions on foreign policy and state law.

The federal judiciary is not only decentralized, but also, in comparison to the Presidency, it is slow and error-prone. Federal courts are notorious for the lengthy delays-often amounting to years-between the filing of a case and the issuance of a judgment. Such delay, when combined with decentralization, prevents the judicial system as an organization from communicating effectively among its units and correcting errors. The mechanism within the federal judiciary for such feedback is the appeal system. ${ }^{46}$ If a trial court reaches the wrong decision on foreign policy, the length of time required to carry out an appeal allows errors to lay uncorrected for months, if not years. Even if the error is obvious and clear, parties must engage in further litigation to correct it. Standards of review designed to conserve the energy of appellate and trial courts-such as the clearly erroneous standard for fact-finding-mean that errors made concerning some issues may remain almost impossible to review on appeal.

Finally, if the Court were to recognize a more vigorous dormant foreign affairs power, the nature of the federal judiciary would undermine the effort to promote rationality in our foreign affairs decision-making. Federal courts simply do not enjoy the flexibility needed to constantly calculate costs and benefits in foreign policy and to adjust the creation and implementation of policy to meet changes in those calculations. Once the courts perceive a mandate arising out of the Constitution or a statute, they have a duty to promote that federal directive in the context of an Article III case or controversy. They have no discretion to adjust those policies

43. See The Federal Judiciary Homepage, Frequently Asked Questions, at http:// www.uscourts.gov/faq.html\#district (last visited July 3, 2001) (stating number of federal district courts in United States).

44. See id. (stating number of federal courts of appeals in United States).

45. See, e.g., Statistics Division, Administrative Office of the United States Courts, Federal Judicial Caseload Statistics: March 31, 2000 (2000) (stating that for year ending March 31, 2000, 55,678 cases were terminated by courts of appeals); FindLaw for Legal Professionals, U.S. Supreme Court Opinions: Cases of 1999 (listing seventy-two cases decided by Supreme Court in 1999), at http://caselaw.lp.findlaw.com/scripts/get-

case.pl?court=US\&navby=year\&year=1999. This means that the Supreme Court's yearly docket represents only $.13 \%$ of the caseload handled by the courts of appeals over approximately the same time period.

46. See, e.g., Martin Shapiro, Toward a Theory of Stare Decisis, 1 J. Legal Stud. $125,125-34$ (1972) (explaining that consistency in application of laws is reached through communications that originate from appeal system). 
without some command from the political branches, regardless of the likely effect on American foreign policy. A rational, unitary decisionmaker can take into account new policy goals, new costs and new benefits, but a federal court cannot. The nature of the litigation process only compounds these problems. Litigation is run by interested parties that have no obligation to provide all of the information that a rational decisionmaker might need to reach the best policy choice. Rather, litigation may witness the use of procedures to harass or delay, the failure to reach compromises and the creation of greater uncertainty and inconsistency. ${ }^{47}$

Given all of these characteristics in the federal judicial system and the judicial process, it is not obvious that we should want the courts to make decisions concerning our foreign policy. Decisions in this area can carry heavier consequences than domestic issues. If we want to establish an effective decision-making process for foreign affairs matters, the Court may wish to consider whether the federal courts are as equally disorganized and discordant as the states. When it chooses to confront the dormant foreign affairs power directly, the Court perhaps may decide to defer to the better-equipped political branches, rather than itself, to make foreign policy for the nation.

47. See, e.g., Robert A. Kagan, Adversarial Legalism and American Govermment, 10 J. Pol'y Analysis \& Mcmt. 369, 370 (1991) (noting that "adversarial legalism results in enormously costly, time-consuming, and erratic policy implementation and dispute resolution ..."). 